\title{
Rational Design and Synthesis of Large Stokes Shift 2,6-Sulphur-Disubstituted BODIPYs for Cell Imaging
}

\author{
Abigail E. Reese ${ }^{1,+}$, Charles Lochenie ${ }^{1,+}{ }^{,}$Ailsa Geddis ${ }^{1,2}$, Luana A. Machado ${ }^{3,4,5} \mathbb{D}$, Marcos C. de Souza $^{3} \mathbb{D}$, \\ Flávia F. C. Marques ${ }^{3}$ (D) , Carlos A. de Simone ${ }^{6}$, Marcos M. Gouvêa ${ }^{3}$ (D) , Leandro F. Pedrosa ${ }^{3,4}$, \\ Eufrânio N. da Silva Júnior ${ }^{5, *(\mathbb{D})}$ and Marc Vendrell ${ }^{1, * \mathbb{D}}$
}

Citation: Reese, A.E.; Lochenie, C.; Geddis, A.; Machado, L.A.; de Souza, M.C.; Marques, F.F.C.; de Simone,

C.A.; Gouvêa, M.M.; Pedrosa, L.F.; da Silva Júnior, E.N.; et al. Rational Design and Synthesis of Large Stokes Shift 2,6-Sulphur-Disubstituted BODIPYs for Cell Imaging. Chemosensors 2022, 10, 19. https:// doi.org/10.3390/chemosensors10010019

Academic Editor: Guo-Hui Pan

Received: 23 November 2021 Accepted: 28 December 2021 Published: 4 January 2022

Publisher's Note: MDPI stays neutral with regard to jurisdictional claims in published maps and institutional affiliations.

Copyright: (c) 2022 by the authors. Licensee MDPI, Basel, Switzerland. This article is an open access article distributed under the terms and conditions of the Creative Commons Attribution (CC BY) license (https:// creativecommons.org/licenses/by/ $4.0 /)$.
1 UoE Centre for Inflammation Research, The University of Edinburgh, Edinburgh EH16 4TJ, UK; a.e.reese@sms.ed.ac.uk (A.E.R.); clocheni@exseed.ed.ac.uk (C.L.); a.geddis-1@sms.ed.ac.uk (A.G.)

2 EASTChem School of Chemistry, The University of Edinburgh, Edinburgh EH9 3FJ, UK

3 Institute of Chemistry, Fluminense Federal University, Niterói 24020-141, RJ, Brazil; luanamachado@id.uff.br (L.A.M.); marcoscs@id.uff.br (M.C.d.S.); flaviamarques@id.uff.br (F.F.C.M.); marc.mtgv@gmail.com (M.M.G.); leandropedrosa@id.uff.br (L.F.P.)

4 Department of Chemistry, Fluminense Federal University, Volta Redonda 27213-145, RJ, Brazil

5 Institute of Exact Sciences, Department of Chemistry, Federal University of Minas Gerais, Belo Horizonte 31270-901, MG, Brazil

6 Institute of Physics, University of São Paulo, São Carlos 13560-160, SP, Brazil; casimone@ifsc.usp.br

* Correspondence: eufranio@ufmg.br (E.N.d.S.J.); marc.vendrell@ed.ac.uk (M.V.)

+ These authors contributed equally to the work.

\begin{abstract}
Five new disubstituted 2,6-thioaryl-BODIPY dyes were synthesized via selective aromatic electrophilic substitution from commercially available thiophenols. The analysis of the photophysical properties via absorption and emission spectroscopy showed unusually large Stokes shifts for BODIPY fluorophores (70-100 nm), which makes them suitable probes for bioimaging. Selected compounds were evaluated for labelling primary immune cells as well as different cancer cell lines using confocal fluorescence microscopy.
\end{abstract}

Keywords: fluorophores; probes; microscopy; cytometry; labelling

\section{Introduction}

Compounds containing chalcogen elements-for instance, selenium, tellurium, and sulphur-have wide applications in many areas of science [1-3]. Importantly, they can act as redox centers and modulate the activity of biomolecules [4-6]. Chalcogen atoms can be also introduced in fluorescent structures to fine-tune their optical properties, including absorption/emission wavelengths and photodynamic capabilities [7,8]. In recent years, our research group and others have focused on the preparation of several classes of fluorescent compounds [9-16]. Antitumor compounds with fluorescent properties, optical probes activated by enzymes [17-22], fluorescent amino acids and synthetic peptides for imaging studies [23-30], and more recently, boron-dipyrromethene (BODIPY) derivatives [31-40] have been the targets of many investigations.

BODIPY dyes are versatile fluorescent scaffolds due to their remarkable photophysical properties. These include relatively large molar absorption coefficients, high fluorescence quantum yields, sharp emission bandwidths, and high photostability [41-43]. Moreover, the chemical versatility of the BODIPY core allows their spectroscopic and photophysical properties to be fine-tuned. This family of compounds has been extensively employed in many research fields, including chemosensors [44], photosensitizers [45-49], and OLEDs [50].

The functionalization of BODIPYs with chalcogen groups has multiple motivations, such as the enhancement of their physicochemical properties [51]. Among the BODIPY derivatives already reported in the literature [52], BODIPYs containing sulphur [53-55], 
selenium [56,57], and tellurium [58] atoms have been reported for the detection of hypochlorite or hypochlorous acid, among some applications.

Synthetic methods for the insertion of sulphur atoms into the basic architecture of BODIPYs have been described (Scheme 1); however, many of them require harsh reaction conditions [55]. Rezende and coworkers developed a methodology for the thiocyanation of 3-substituted and 3,5-disubstituted BODIPYs using oxone and ammonium thiocyanate [59]. Kim and coworkers prepared an alkylthioether BODIPY derivatives via an electrophilic substitution reaction in the presence of DMSO and $\mathrm{POCl}_{3}$ [60]. Bröring's group described other interesting examples using $\mathrm{S}_{2} \mathrm{Cl}_{2}$ to dimerize BODIPY moieties as sulfide analogues [61].

(A) Examples of 3-, 3,5-, and meso-S-substituted BODIPYs:

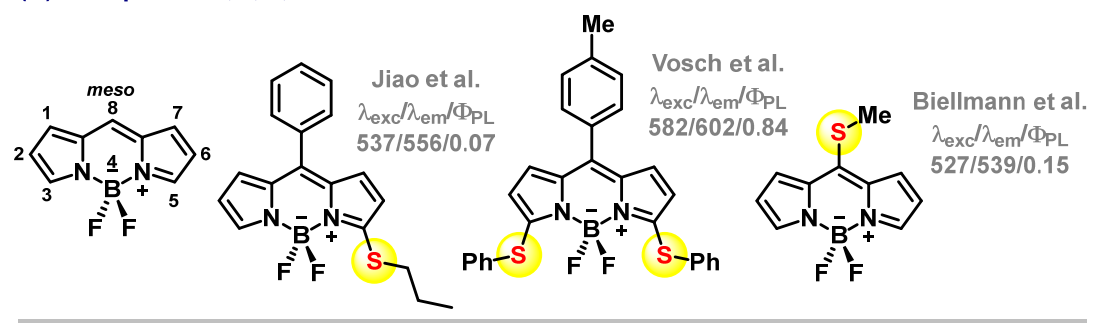

(B) Examples of 2- and 2,6-S-substituted BODIPYs:
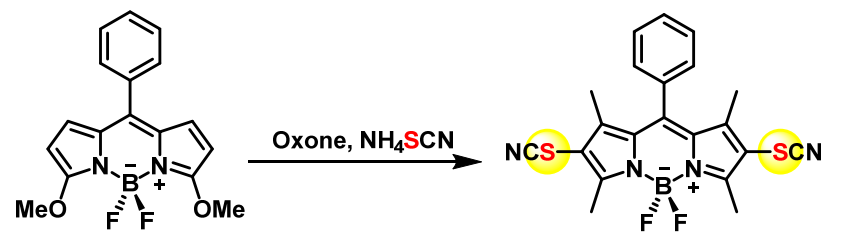

Rezende et al.

$\lambda_{\text {exc }} / \lambda_{\text {em }} / \Phi_{\mathrm{PL}}$

$513 / 553 / 0.10$
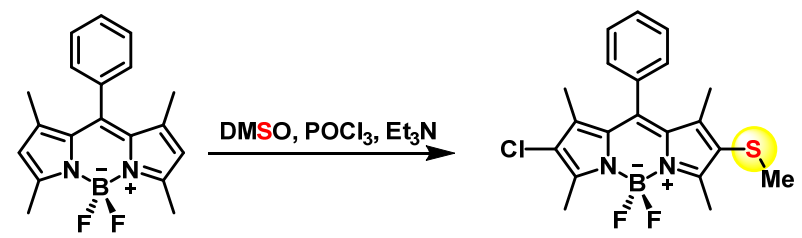

Kim et al.

$\lambda_{\text {exc }} / \lambda_{\text {em }} / \Phi_{\mathrm{PL}}$

$519 / 650 / 0.09$

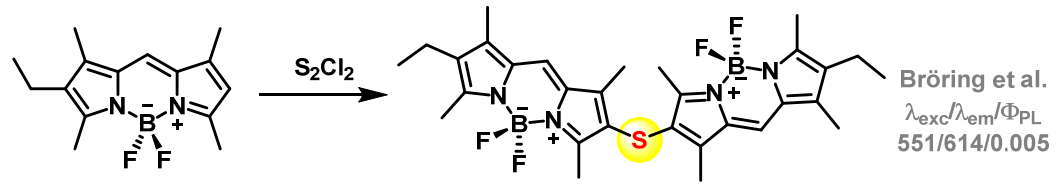

(C) 2,6-Sulphur-Disubstituted BODIPYs for Cell Imaging (This Work):

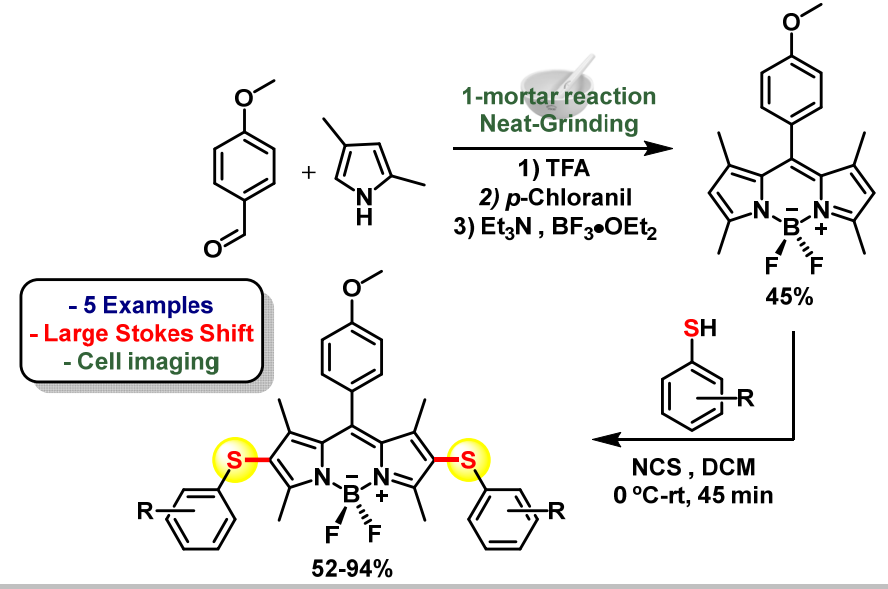

Scheme 1. (A) Examples of 3-, 3,5-, and meso-S-substituted BODIPYs. (B) Examples of 2- and 2,6thiosubstituted BODIPYs. (C) Chemical structures and synthetic strategy for the new fluorophores described in this work. 
Upon compiling existing data on the photophysical properties of the above-mentioned BODIPYs, we observed that while having variable excitation and emission maxima and photoluminescence quantum yields $\left(\Phi_{\mathrm{PL}}\right)$, all 2- and 2,6-thioether-substituted compounds exhibited large Stokes shifts > $50 \mathrm{~nm}[60,61]$ (Scheme 1B), partially due to electron delocalization, whereas the 3-, 3,5- and meso-thioether-substituted BODIPYs displayed smaller excitation-emission gaps of 10 to $30 \mathrm{~nm}$ (Scheme 1A) [53-55]. Because large Stokes shifts can improve signal-to-noise ratios or allow excitation of multiple dyes with the same laser source, they can be advantageous for bioimaging applications. Therefore, we designed new 2,6-sulphur-disubstituted BODIPYs based on thiophenol derivatives. Herein we present an optimized 2-step synthesis from readily available building blocks, their photophysical properties in different solvents, and potential use as probes for live-cell imaging (Scheme 1C).

\section{Materials and Methods}

\subsection{Chemistry}

All reagents and solvents used were of analytical grade. ${ }^{1} \mathrm{H},{ }^{13} \mathrm{C}$, and ${ }^{19} \mathrm{~F}$ spectra were recorded on a Varian VNMRS $300 \mathrm{MHz}$ and Varian VNMRS $500 \mathrm{MHz}$ spectrometer, using tetramethylsilane (TMS) or trifluoroacetic acid (TFA) as reference. Spectra were recorded typically at r.t. in $\mathrm{CDCl}_{3}$. Chemical shifts are reported in ppm $(\delta)$ and coupling constants $(J)$ are given in Hz. Column chromatographic purifications were carried out on silica gel SiliaFlash G60 70-230 mesh (SiliCycle) columns with the defined eluents. NMR spectra and HRMS data are presented in Supporting Information.

4,4-Difluoro-8-(4-methoxyphenyl)-1,3,5,7-tetramethyl-4-bora-3a,4a-diaza-S-indacene (1): 2,4dimethyl-1H-pyrrole (1.03 mL, $10.0 \mathrm{mmol})$ and 4-methoxybenzaldehyde $(0.61 \mathrm{~mL}, 5.0 \mathrm{mmol})$ were mixed with a pestle and mortar. Trifluoroacetic acid was added and the mixture was ground for $2 \mathrm{~min}$. $\mathrm{CHCl}_{3}(2.0 \mathrm{~mL})$ was added and then $p$-chloranil $(1.81 \mathrm{~g}, 7.4 \mathrm{mmol})$ was added to the mixture and ground for $2 \mathrm{~min}$. Next, triethylamine $(6.0 \mathrm{~mL}, 43.0 \mathrm{mmol})$ was added and the resulting paste was ground for $3 \mathrm{~min} . \mathrm{BF}_{3} \cdot \mathrm{OEt}_{2}(6.0 \mathrm{~mL}, 47.4 \mathrm{mmol})$ was then added dropwise and the mixture was ground for 2 min until a dark red paste formed. The reaction mixture was dissolved in $\mathrm{CHCl}_{3}(200 \mathrm{~mL})$ and washed with saturated $\mathrm{Na}_{2} \mathrm{CO}_{3}$ $(3 \times 200 \mathrm{~mL})$ and brine $(2 \times 200 \mathrm{~mL})$. The solvent was evaporated and the crude solid was purified by normal-phase chromatography with hexane:chloroform (9:1). The product was obtained as an orange solid (45\% yield). $\left.{ }^{1} \mathbf{H} \mathbf{~ N M R ~ ( 5 0 0 ~} \mathbf{M H z}, \mathbf{C D C l}_{3}\right) \delta$ : 7.18-7.16 $(\mathrm{d}, J=8.7 \mathrm{~Hz}, 2 \mathrm{H}), 7.02-7.00(\mathrm{~d}, J=8.7 \mathrm{~Hz}, 2 \mathrm{H}), 5.97(\mathrm{~s}, 2 \mathrm{H}), 3.87(\mathrm{~s}, 3 \mathrm{H}), 2.55(\mathrm{~s}, 6 \mathrm{H}), 1.43$ $(\mathrm{s}, 6 \mathrm{H})$ ppm. ${ }^{19} \mathbf{F}$ NMR (470 $\left.\mathbf{M H z}, \mathbf{C D C l}_{3}\right) \delta:-143.5\left(\mathrm{q}, J_{B F}=32.9 \mathrm{~Hz}\right) \mathrm{ppm} .{ }^{13} \mathbf{C} \mathbf{~ N M R}$ $\left(75 \mathbf{~ M H z}, \mathbf{C D C l}_{3}\right) \delta: 160.27,155.39,143.29,141.99,131.98,127.1,121.2,114.6,55.4,14.6$ ppm. The data are consistent with those reported in the literature [62].

Synthesis of thioaryl-BODIPYs (2a-e): To a suspension of $N$-chlorosuccinimide $(267 \mathrm{mg}$, $2 \mathrm{mmol})$ in $\mathrm{CH}_{2} \mathrm{Cl}_{2}(10 \mathrm{~mL})$ at r.t., we carried out a dropwise addition of a solution of the corresponding thiophenol $(2 \mathrm{mmol})$ in dry $\mathrm{CH}_{2} \mathrm{Cl}_{2}(10 \mathrm{~mL})$. After stirring for $30 \mathrm{~min}$, the orange solution of the phenyl-sulfenyl chloride was used in situ. To the solution of phenyl-sulfenyl chloride at $0^{\circ} \mathrm{C}$, a solution of BODIPY $1(50.0 \mathrm{mg}, 0.135 \mathrm{mmol})$ in $10 \mathrm{~mL}$ of dry $\mathrm{CH}_{2} \mathrm{Cl}_{2}$ was added dropwise over $15 \mathrm{~min}$. The mixture was stirred at r.t. for $15 \mathrm{~min}$. Next, $\mathrm{H}_{2} \mathrm{O}(20 \mathrm{~mL})$ was added to the reaction mixture. After separation, the organic phase was washed with $\mathrm{H}_{2} \mathrm{O}(20 \mathrm{~mL})$, dried over $\mathrm{Na}_{2} \mathrm{SO}_{4}$, and the solvent was evaporated under reduced pressure. The residue was purified by column chromatography using hexane: $\mathrm{CH}_{2} \mathrm{Cl}_{2}(8: 1)$ to give the products $2 \mathrm{a}-\mathbf{e}$.

4,4-Difluoro-8-(4-methoxyphenyl)-2,6-bis(phenylthio)-1,3,5,7-tetramethyl-4-bora-3a,4a-diaza-Sindacene (2a): The product was obtained as a red solid (94\% yield; m.p. $\left({ }^{\circ} \mathrm{C}\right)$ 225-228; ${ }^{\mathbf{1}} \mathbf{H}$ NMR $\left(500 \mathrm{MHz} \mathrm{CDCl}_{3}\right) \delta: 7.22-7.19(\mathrm{~m}, 6 \mathrm{H}), 7.11-7.08(\mathrm{t}, \mathrm{J}=7.4 \mathrm{~Hz}, 2 \mathrm{H}), 7.04-7.03(\mathrm{~d}, J=8.7 \mathrm{~Hz}$, 2H), 7.01-7.00 (d, $J=7.3 \mathrm{~Hz}, 4 \mathrm{H}), 3.87(\mathrm{~s}, 3 \mathrm{H}), 2.62(\mathrm{~s}, 6 \mathrm{H}), 1.54(\mathrm{~s}, 6 \mathrm{H}) .{ }^{19}$ F NMR (470 MHz, $\left.\mathrm{CDCl}_{3}\right) \delta:-143.11(\mathrm{q}, J=31.7 \mathrm{~Hz}) .{ }^{13} \mathrm{C} \mathbf{N M R}\left(75 \mathbf{M H z}, \mathbf{C D C l}_{3}\right) \delta: 160.6,160.1,148.5,143.3$, 137.5, 132.0, 129.1, 126.7, 126.0, 125.3, 115.0, 77.1, 55.5, 13.6, 13.3. ESI ${ }^{+} / \mathbf{H R M S}(\mathrm{m} / z)[\mathrm{M}+\mathrm{H}]^{+}$: 
571.1855 Cald. for $\mathrm{C}_{32} \mathrm{H}_{30} \mathrm{BF}_{2} \mathrm{~N}_{2} \mathrm{OS}_{2}$, found: 571.1850. Data are consistent with those reported in the literature.

4,4-Difluoro-8-(4-methoxyphenyl)-2,6-bis(2-methylphenylthio)-1,3,5,7-tetramethyl-4-bora-3a,4adiaza-S-indacene $(\mathbf{2 b})$ : The product was obtained as a red solid $\left(83 \%\right.$ yield); m.p. $\left({ }^{\circ} \mathrm{C}\right)$ 223-229; ${ }^{1}$ H NMR (300 MHz, $\left.\left.\mathrm{CDCl}_{3}\right) \delta: 7.25-7.22(\mathrm{~d}, J=8.7 \mathrm{~Hz}, 2 \mathrm{H})\right), 7.14-7.11(\mathrm{~m}, 2 \mathrm{H}), 7.05-7.00(\mathrm{~m}$, $6 \mathrm{H}), 6.63-6.60(\mathrm{~m}, 2 \mathrm{H}), 3.78(\mathrm{~s}, 3 \mathrm{H}), 2.52(\mathrm{~s}, 6 \mathrm{H}), 2.33(\mathrm{~s}, 6 \mathrm{H}), 1.43(\mathrm{~s}, 6 \mathrm{H}) .{ }^{19}$ F NMR (470 MHz, $\left.\mathrm{CDCl}_{3}\right) \delta:-143.11(\mathrm{q}, J=31.7 \mathrm{~Hz}) .{ }^{13} \mathrm{C}$ NMR (75 MHz, $\left.\mathbf{C D C l}_{3}\right) \delta: 160.6,160.1,148.7,143.1$, 136.5, 134.8, 130.2, 129.2, 126.7, 126.6, 124.9, 124.7, 115.0, 77.1, 55.5, 20.0, 13.5, 13.3. ESI /HRMS $^{-\mathrm{HR}}$ $(m / z)[\mathrm{M}+\mathrm{H}]^{+}: 599.2168$ Cald. for $\mathrm{C}_{34} \mathrm{H}_{34} \mathrm{BF}_{2} \mathrm{~N}_{2} \mathrm{OS}_{2}$, found: 599.2162 .

4,4-Difluoro-8-(4-methoxyphenyl)-2,6-bis(4-methylphenylthio)-1,3,5,7-tetramethyl-4-bora-3a,4adiaza-S-indacene (2c): The product was obtained as a pink solid (63\% yield); m.p. $\left({ }^{\circ} \mathrm{C}\right) 225-229$; ${ }^{1} \mathbf{H}$ NMR (500 MHz, $\left.\mathbf{C D C l}_{3}\right) \delta: 7.21-7.20(\mathrm{~d}, J=8.6 \mathrm{~Hz}, 2 \mathrm{H}), 7.04-7.01(\mathrm{~m}, 6 \mathrm{H}), 6.92-6.91(\mathrm{~d}, J$ $=8.2 \mathrm{~Hz}, 4 \mathrm{H}), 3.86(\mathrm{~s}, 3 \mathrm{H}), 2.27(\mathrm{~s}, 6 \mathrm{H}), 1.53(\mathrm{~s}, 6 \mathrm{H}) .{ }^{19} \mathbf{F}$ NMR $\left(470 \mathbf{~ M H z}, \mathbf{C D C l}_{3}\right) \delta:-148.08$ $(\mathrm{q}, J=31.5 \mathrm{~Hz}) .{ }^{13} \mathrm{C}$ NMR (125 MHz, $\left.\mathbf{C D C l}_{3}\right) \delta: 160.6,160.0,148.3,143.2,135.3,133.9,132.0$, $129.9,129.2,126.8,126.4,115.0,55.5,13.6,13.4$. ESI $^{+} / \mathbf{H R M S}(m / z)[\mathrm{M}+\mathrm{H}]^{+}: 599.2168$ Cald. for $\mathrm{C}_{34} \mathrm{H}_{34} \mathrm{BF}_{2} \mathrm{~N}_{2} \mathrm{OS}_{2}$, found: 599.2163 .

4,4-Difluoro-8-(4-methoxyphenyl)-2,6-bis(4-methoxiphenylthio)-1,3,5,7-tetramethyl-4-bora-3a,4adiaza-S-indacene (2d): The product was obtained as a deep red solid $\left(90 \%\right.$ yield); m.p. $\left({ }^{\circ} \mathrm{C}\right)$ 234-238; ${ }^{1} \mathbf{H}$ NMR $\left(500\right.$ MHz, $\left.\mathbf{C D C l}_{3}\right) \delta$ : 7.19-7.18 (d, J = 8.7 Hz, 2H), 7.03-7.02 (d, J = 8.7 Hz, 2H), 7.01-6.99 (d, $J=8.9 \mathrm{~Hz}, 4 \mathrm{H}), 6.78-6.76(\mathrm{~d}, J=8.9 \mathrm{~Hz}, 4 \mathrm{H}), 3.79(\mathrm{~s}, 3 \mathrm{H}), 3.68(\mathrm{~s}, 6 \mathrm{H}), 2.55$ (s, 6H), $1.46(\mathrm{~s}, 6 \mathrm{H}) .{ }^{19} \mathrm{~F}$ NMR (470 MHz, $\left.\mathrm{CDCl}_{3}\right) \delta:-143.17(\mathrm{q}, J=31.7 \mathrm{~Hz}) .{ }^{13} \mathrm{C} \mathrm{NMR}(\mathbf{1 2 5} \mathbf{~ M H z}$, $\mathrm{CDCl}_{3}$ ) $\delta: 160.6,159.7,158.2,147.7,143.0,131.8,129.2,128.8,127.9,126.8,122.3,114.9,114.8$, 77.1, 55.5, 13.6, 13.4. ESI ${ }^{+} /$HRMS $(m / z)[M+H]^{+}: 631.2066$ Cald. for $\mathrm{C}_{34} \mathrm{H}_{34} \mathrm{BF}_{2} \mathrm{~N}_{2} \mathrm{O}_{3} \mathrm{~S}_{2}$, found: 631.2057 .

4,4-Difluoro-8-(4-methoxyphenyl)-2,6-bis(4-chlorophenylthio)-1,3,5,7-tetramethyl-4-bora-3a,4adiaza-S-indacene (2e): The product was obtained as a deep red solid (52\% yield); m.p. $\left({ }^{\circ} \mathrm{C}\right)$ 230-235; ${ }^{1} \mathbf{H}$ NMR (500 MHz, $\left.\mathbf{C D C l}_{3}\right) \delta: 7.21-7.19(\mathrm{~d}, J=8.8 \mathrm{~Hz}, 2 \mathrm{H}), 7.18-7.17(\mathrm{~d}, J=8.7$ $\mathrm{Hz}, 4 \mathrm{H}), 7.05-7.03(\mathrm{~d}, J=8.7 \mathrm{~Hz}, 2 \mathrm{H}), 6.93-6.91(\mathrm{~d}, J=8.7 \mathrm{~Hz}, 4 \mathrm{H}), 3.52(\mathrm{~s}, 3 \mathrm{H}), 2.57(\mathrm{~s}, 6 \mathrm{H})$, $1.47(\mathrm{~s}, 6 \mathrm{H}) .{ }^{19} \mathrm{~F}$ NMR (470 MHz, $\left.\mathbf{C D C l}_{3}\right) \delta:-148.01(\mathrm{q}, J=31.7 \mathrm{~Hz}) .{ }^{13} \mathrm{C}$ NMR (125 MHz, $\mathrm{CDCl}_{3}$ ) $\delta: 160.7,160.0,148.6,143.6,136.0,132.1,131.2,129.2,129.1,127.3,126.5,120.3,115.1$, 77.1, 55.5, 13.5, 13.3. ESI $/$ HRMS $(m / z)[\mathrm{M}+\mathrm{H}]^{+}: 639.1076$ Cald. for $\mathrm{C}_{32} \mathrm{H}_{28} \mathrm{BCl}_{2} \mathrm{~F}_{2} \mathrm{~N}_{2} \mathrm{OS}_{2}$, found: 639.1076 .

\subsection{Photophysical Measurements}

Absorption spectra were obtained on a UV-visible spectrophotometer (Thermo Scientific Evolution 600) at r.t. Fluorescence excitation and emission spectra were recorded on a Varian Cary Eclipse spectrofluorometer using $1 \mathrm{~cm}$ pathlength cuvettes at r.t. Fluorescence quantum yields $\left(\Phi_{\mathrm{F}}\right)$ of the new compounds were obtained from a comparative method using Rhodamine 6G $\left(\Phi_{\mathrm{F}}=0.95\right.$ in ethanol, $\left.\lambda_{\mathrm{exc}}=500 \mathrm{~nm}\right)$ as a standard [63]. In this method, a series of solutions in different concentrations were used for measurements of absorbance and fluorescence emission, keeping a low absorbance $(\mathrm{A}<0.1)$ to avoid inner-filter effects and intermolecular reabsorption [64]. The quantum yield was calculated by plotting the integrated fluorescence intensity vs. absorbance to obtain the slope of the curve. The photoluminescence quantum yield of the tested compound $\left(\Phi_{\mathrm{x}}\right)$ was calculated using the following equation

$$
\Phi_{\mathrm{x}}=\Phi_{\text {st }}\left(\frac{\operatorname{Grad}_{\mathrm{x}}}{\operatorname{Grad}_{\mathrm{st}}}\right)\left(\frac{\eta_{\mathrm{x}}^{2}}{\eta_{\mathrm{st}}^{2}}\right)
$$

where $\Phi_{\text {st }}$ is the quantum yield of the standard, $\operatorname{Grad}_{x}$ and $\operatorname{Grad}_{\text {st }}$ are the slopes for the test and standard compounds, respectively, and $\eta_{x}$ and $\eta_{\text {st }}$ are the refractive indexes of the solvents.

\subsection{Biological Experiments}

Viability assays: Cell lines were cultured in DMEM supplemented with 10\% FBS, antibiotics (100 $\mathrm{U} \mathrm{mL}^{-1}$ penicillin and $100 \mathrm{mg} \mathrm{mL}^{-1}$ streptomycin) and $1 \%$ L-Glutamine at 
$37^{\circ} \mathrm{C}$ in a humidified atmosphere with $5 \% \mathrm{CO}_{2}$. Cells were regularly passaged in T-75 flasks using trypsin-EDTA. Cells were plated at a density of 10,000 cells per well and incubated overnight with the fluorophores $(10 \mu \mathrm{M})$. Cell viability was assessed using an MTT cell proliferation assay following the manufacturer's instructions. Values were normalized to the viability of untreated cells and analysed by GraphPad Prism.

Work with peripheral blood cells: The study protocol to work with human peripheral blood leukocytes was approved by the Accredited Medical Regional Ethics Committee (AMREC, 20-HV-069, University of Edinburgh). Human blood leukocytes were isolated from healthy volunteers and processed as described previously [65]. Briefly, whole blood was anticoagulated with sodium citrate $0.4 \%(w / v)$ and centrifuged at $350 \times g$ for $20 \mathrm{~min}$. Polymorphonuclear cells (>95\% neutrophils) were harvested from the $63 \% / 72.9 \%$ interface and cultured in RPMI with 5\% FBS, $100 \mathrm{U} \mathrm{mL}^{-1}$ penicillin, and $100 \mu \mathrm{g} \mathrm{mL}^{-1}$ streptomycin. Neutrophils were stimulated with $10 \mathrm{nM}$ PMA for $3 \mathrm{~h}$ at $37^{\circ} \mathrm{C}$. Monocytes were separated from the $49.5 \% / 63 \%$ interface and cultured for 10 days in IMDM supplemented with 5\% autologous serum to yield monocyte-derived macrophages (MDMs). Cells were plated and cultured with or without $5 \mathrm{ng} / \mathrm{mL}$ LPS at $37^{\circ} \mathrm{C}$.

\subsection{Fluorescence Confocal Microscopy}

Cells were plated in glass chamber slides (Nunc $\left.{ }^{\mathrm{TM}} \mathrm{Lab}^{\mathrm{Te}} \mathrm{k}^{\mathrm{TM}} \mathrm{II}\right)$ and incubated with compounds 1 or $2 \mathrm{a}(10 \mu \mathrm{M})$ and Hoechst $33342(0.1 \mu \mathrm{g} / \mathrm{mL})$ for $15 \mathrm{~min}$. Cells were washed and imaged using a Leica SP8 confocal microscope using $488 \mathrm{~nm}$ laser for excitation. All resulting images were analysed using FIJI.

\subsection{Crystallography}

Single, clear, light, colourless block-shaped crystals of $\mathbf{2} \mathbf{d}$ were obtained by recrystallization from slow evaporation. A suitable crystal $0.22 \times 0.20 \times 0.15 \mathrm{~mm}^{3}$ was selected and mounted on a suitable support on an XtaLAB Mini (ROW) diffractometer. The crystal was kept at a steady $T=293(2) \mathrm{K}$ during data collection. The structure was solved with the ShelXT [66] structure solution program using the intrinsic phasing solution method and by using Olex2 [67] as the graphical interface. The model was refined with version 2017/1 of ShelXL 2017/1 [68] using least-squares minimization.

\section{Results}

The synthesis of the target compounds started with the preparation of BODIPY structure 1 as shown in Scheme 2. Compound 1 was synthesized from 2,4-dimethyl-1H-pyrrole and 4-methoxybenzoldehyde condensation, followed by oxidation with $p$-chloranil and complexation with $\mathrm{BF}_{3} \cdot \mathrm{OEt}_{2}$. The one-pot reaction was performed by grinding the starting materials using a simple mortar affording the compound 1, and the optimized reaction procedure raised the recovery yields from 19 to $45 \%$ [62]. The use of neat conditions also led to faster reaction times $(15 \mathrm{~min})$ in comparison to conventional BODIPY synthesis.
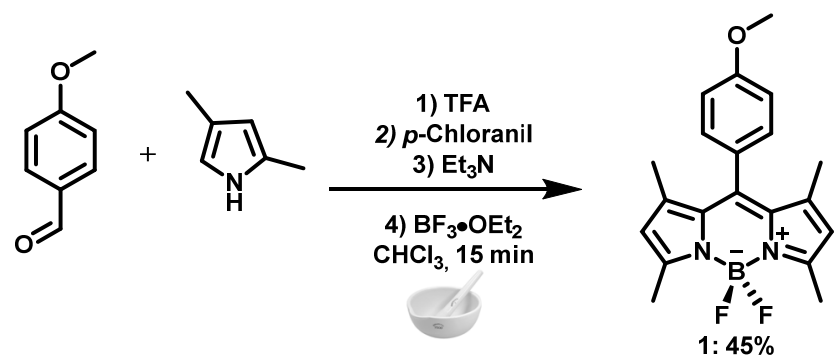

Scheme 2. Synthesis of the BODIPY compound 1 obtained from the reaction of 2,4-dimethyl- $1 H$ pyrrole and 4-methoxybenzoldehyde.

With the BODIPY derivative 1 in hand, we prepared 2-, and 6-thioaryl-substituted BODIPY dyes as outlined in Scheme 3. Arylthiol chlorides were prepared in situ from $N$ - 
chlorosuccinimide and commercially available thiophenols, and then used for the selective electrophilic substitution of the positions 2 and 6 of compound 1, which are known to be more susceptible to electrophilic attack [59]. The new 2,6-substituted thioaryl-BODIPYs 2a-e were obtained in moderate to high yields (52-94\%), and fully characterized by ${ }^{1} \mathrm{H}$, ${ }^{13} \mathrm{C}$ and ${ }^{19} \mathrm{~F}$ NMR spectroscopy and high-resolution mass spectrometry. Suitable crystals of compound $\mathbf{2 d}$ were obtained by the slow evaporation method using chloroform as solvent. With appropriate red crystals in hand, the structure of $\mathbf{2} \mathbf{d}$ was solved and reconfirmed by X-ray crystallographic analysis. Representative Oak Ridge thermal ellipsoid plot (ORTEP)-3 diagram for $\mathbf{2 d}$ is displayed in Figure S1 and the crystallographic data is shown in Table S1.<smiles>COc1ccc(C2=C3C(C)=CC(C)=[N+]3[B-](F)(F)n3c(C)cc(C)c32)cc1</smiles>

1<smiles>[R]c1cccc(S)c1</smiles>

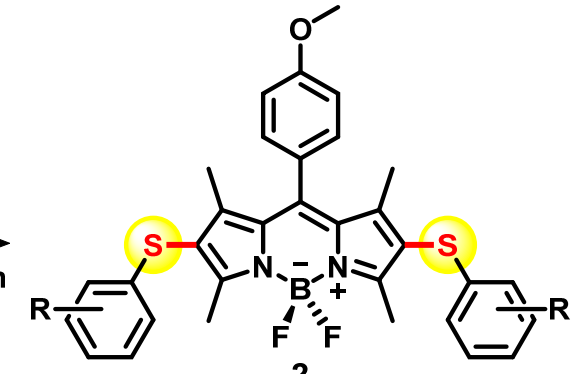

2<smiles>COc1ccc(C2=C3C(C)=C(Sc4ccccc4)C(C)=[N+]3[B-](F)(F)n3c(C)c(Sc4ccccc4)c(C)c32)cc1</smiles>

2a: $94 \%$<smiles>COc1ccc(C2=C3C(C)=C(Sc4ccccc4C)C(C)=[N+]3[B-](F)(F)n3c(C)c(Sc4ccccc4C)c(C)c32)cc1</smiles>

2b: $83 \%$<smiles>Cc1ccc(S)cc1</smiles><smiles></smiles>

2d: $90 \%$<smiles>COc1ccc(C2=C3C(C)=C(Sc4ccc(C)cc4)C(C)=[N+]3[B-](F)(F)n3c(C)c(I)c(C)c32)cc1</smiles><smiles>COc1ccc(SC2=C(C)C3=C(c4ccc(OC)cc4)c4c(C)c(Sc5ccc(OC)cc5)c(C)n4[B-](F)(F)[N+]3=C2C)cc1</smiles>

Scheme 3. Synthesis and chemical structures of sulphur-containing BODIPY derivatives (2a-2e).

The photophysical properties (absorption/emission wavelengths and relative photoluminescence quantum yields) of compounds $\mathbf{2 a}-\mathbf{2} \mathbf{e}$ were determined in different relevant solvents, namely toluene, tetrahydrofuran (THF), acetone, methanol (MeOH), dimethylsulfoxide (DMSO), and water (including 1\% DMSO). These results are summarized in Figure 1 and Table 1. In general, no relevant solvatochromic properties were observed (Figure S2 and Table 1). All compounds presented a large Stokes shift (70-100 nm, 2200-3200 cm $\left.{ }^{-1}\right)$ with absorption maxima around 515-525 nm and emission maxima around 595-620 nm in toluene. Notably, this large Stokes shift was not observed for the unsubstituted parent compound 1, highlighting the increased electronic delocalization in thio-containing compounds. We also observed that the emission wavelengths shifted from $\sim 590 \mathrm{~nm}$ for the most electron-poor thioaryl group (2e, 4-Cl-Ph, toluene) to $\sim 618 \mathrm{~nm}$ for the most electron-rich substituent (2d, 4-OMe-Ph, toluene); however, the absorption maxima remain unchanged 
(519 and $521 \mathrm{~nm}$ for $\mathbf{2 d}$ and 2e). In most BODIPY dyes, it has been reported that the HOMO is localized on the $\pi$-system of the pyrrole rings, whereas the LUMO sits on a mix of the $\pi$-system and the meso position [69]; however, with the introduction of the thioaryl groups on positions 2 and 6 of the BODIPY core, the compound may undergo heavy-atom-free intersystem crossing via photoinduced electron transfer (PET) as observed in some BODIPY dyads [45].

Next, to evaluate the applicability of our new BODIPY fluorophores for live-cell imaging, we performed cell viability assays. For these experiments, we used breast cancer cells MDA-MB-231 as a representative cell line. All our new compounds (2a-2e) did not show any significant cytotoxicity when incubated with the cells for $16 \mathrm{~h}$ at $10 \mu \mathrm{M}$, and adverse effects on cell viability were only detected at very high concentrations (i.e., $>100 \mu \mathrm{M}$, Figure S3). Because the photophysical properties of our new BODIPY fluorophores are relatively similar, we decided to assess the application of compound $\mathbf{2 a}$, the simplest disubstituted thioaryl-BODIPY compound, for live-cell imaging experiments.

First, we evaluated the ability of compound $2 \mathbf{a}$ to label different human cancer cell lines, namely MDA-MB-231 and MCF7 (both breast cancer cells) and HT29 (colorectal carcinoma). Cells were incubated with compound 2a $(10 \mu \mathrm{M})$ and Hoechst 33342 for 15 min prior to acquiring images under the fluorescence confocal microscope $\left(\lambda_{\text {exc }}: 488 \mathrm{~nm}, \lambda_{\mathrm{em}}\right.$ : 550-680 nm). Figure 2 shows that compound 2a was taken up by cancer cells, with slightly brighter staining being observed in breast cancer cells than in colorectal cancer cells, which could be due to differences in the expression of transporters or efflux pumps between these cell lines. The parent compound 1 was also able to stain MCF7 cells with a similar intracellular distribution than compound 2a (Figure S4).

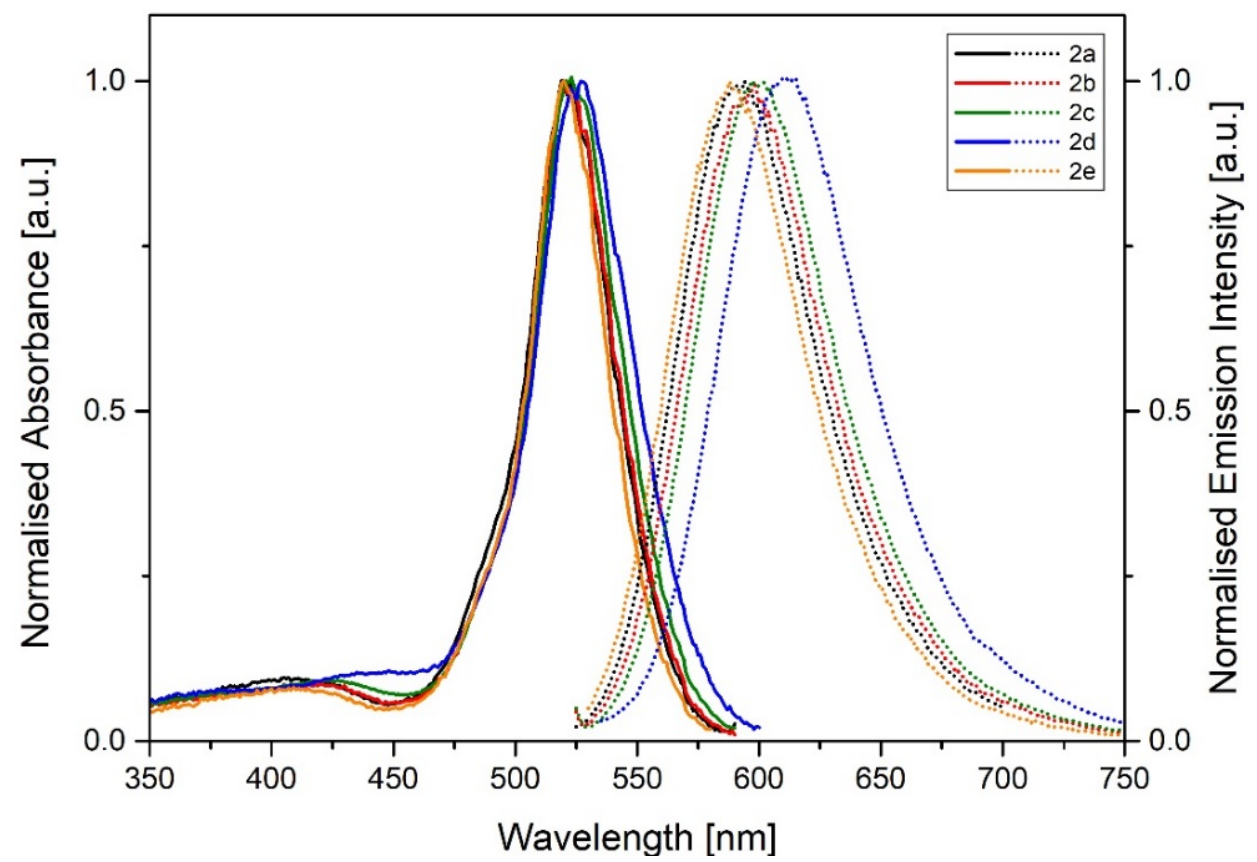

Figure 1. Absorbance and emission spectra of the BODIPY compounds (2a-2e) in toluene. 
Table 1. Photophysical properties of BODIPY compounds (2a-2e) and the standard BODIPY FL.

\begin{tabular}{|c|c|c|c|c|c|}
\hline Compound & Solvent & $\begin{array}{l}\lambda_{\mathrm{abs}} \\
{[\mathrm{nm}]}\end{array}$ & $\begin{array}{c}\lambda_{\mathrm{em}} \\
{[\mathrm{nm}]}\end{array}$ & $\begin{array}{l}\text { Stokes Shift } \\
{\left[\mathrm{cm}^{-1}\right]}\end{array}$ & $\Phi_{\mathrm{PL}}$ \\
\hline \multirow{6}{*}{$2 a$} & Toluene & 521 & 595 & 2387 & 0.27 \\
\hline & $\mathrm{THF}$ & 520 & 593 & 2340 & 0.18 \\
\hline & Acetone & 516 & 597 & 2629 & 0.1 \\
\hline & $\mathrm{MeOH}$ & 516 & 600 & 2713 & 0.1 \\
\hline & DMSO & 517 & 605 & 2813 & 0.07 \\
\hline & Water (1\% DMSO) & 516 & 606 & 2878 & 0.02 \\
\hline \multirow{6}{*}{$2 b$} & Toluene & 523 & 599 & 2426 & 0.24 \\
\hline & THF & 520 & 599 & 2536 & 0.13 \\
\hline & Acetone & 519 & 600 & 2601 & 0.08 \\
\hline & $\mathrm{MeOH}$ & 517 & 602 & 2731 & 0.05 \\
\hline & DMSO & 518 & 613 & 2991 & 0.07 \\
\hline & Water (1\% DMSO) & 519 & 612 & 2928 & 0.03 \\
\hline \multirow{6}{*}{$2 c$} & Toluene & 524 & 599 & 2389 & 0.2 \\
\hline & THF & 521 & 602 & 2583 & 0.12 \\
\hline & Acetone & 518 & 607 & 2831 & 0.05 \\
\hline & $\mathrm{MeOH}$ & 519 & 607 & 2793 & 0.05 \\
\hline & DMSO & 522 & 616 & 2923 & 0.02 \\
\hline & Water (1\% DMSO) & 520 & 614 & 2944 & $<0.01$ \\
\hline \multirow{6}{*}{$2 d$} & Toluene & 519 & 618 & 3087 & 0.14 \\
\hline & THF & 517 & 619 & 3187 & 0.03 \\
\hline & Acetone & 516 & 619 & 3225 & $<0.01$ \\
\hline & $\mathrm{MeOH}$ & 514 & 619 & 3300 & $<0.01$ \\
\hline & DMSO & 513 & 620 & 3364 & $<0.01$ \\
\hline & Water (1\% DMSO) & 515 & 622 & 3340 & $<0.01$ \\
\hline \multirow{6}{*}{$2 e$} & Toluene & 521 & 590 & 2245 & 0.26 \\
\hline & THF & 517 & 589 & 2364 & 0.2 \\
\hline & Acetone & 512 & 592 & 2639 & 0.12 \\
\hline & $\mathrm{MeOH}$ & 515 & 591 & 2497 & 0.11 \\
\hline & DMSO & 518 & 599 & 2610 & 0.05 \\
\hline & Water (1\% DMSO) & 513 & 600 & 2826 & 0.01 \\
\hline BODIPY-FL & DMSO & 503 & 509 & 234 & 0.97 \\
\hline
\end{tabular}



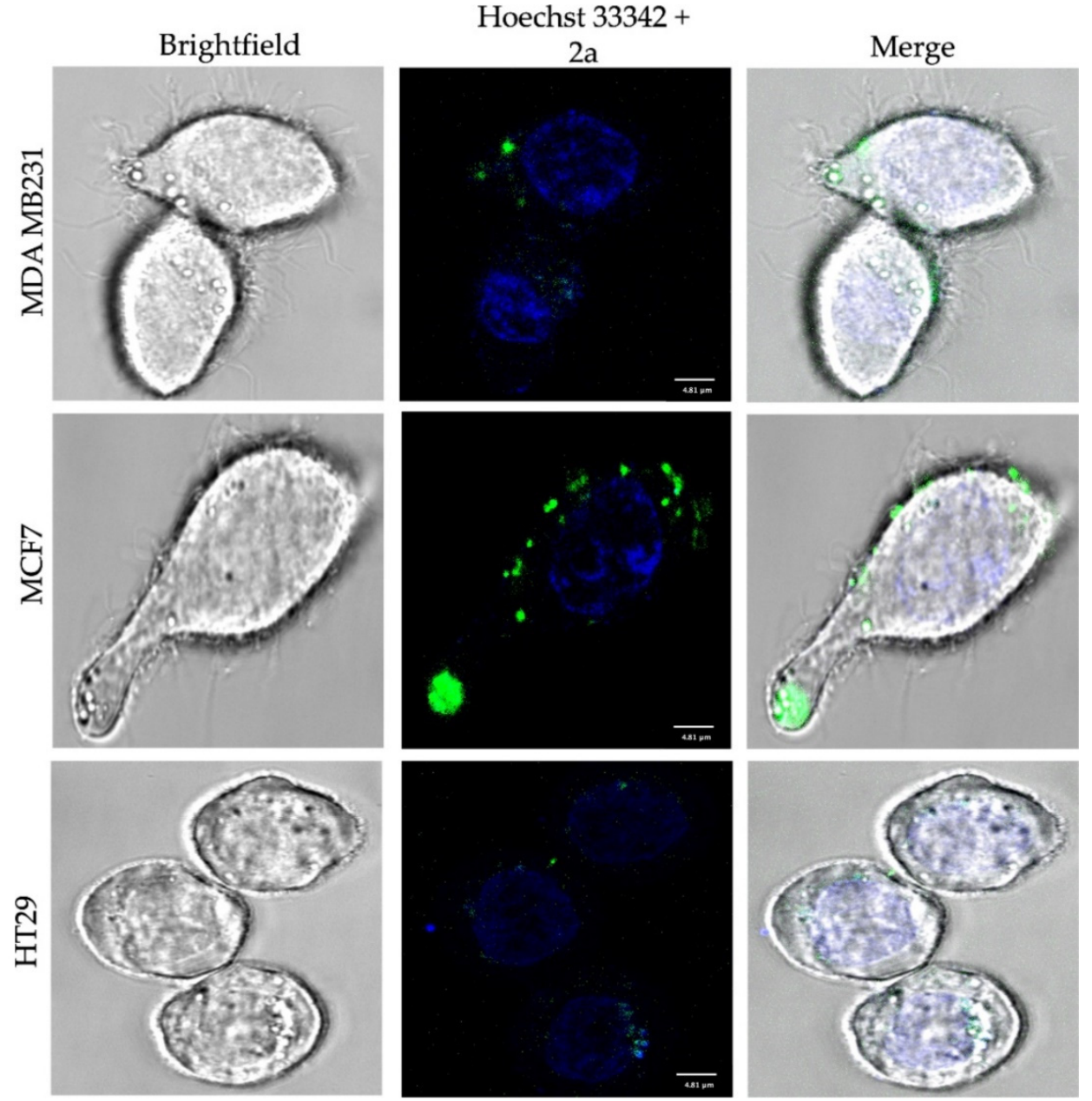

Figure 2. Confocal fluorescence microscopy images of compound $2 \mathbf{a}\left(10 \mu \mathrm{M}, \lambda_{\mathrm{exc}}=488 \mathrm{~nm}, \lambda_{\mathrm{em}}=\right.$ 550-680 nm) in MDA-MB-231 and MCF7 (breast cancer cells) as well as HT29 (colorectal carcinoma cells). Cells were counterstained with Hoechst 33342 for nuclear labelling. Scale bar: $5 \mu \mathrm{m}$.

Next, we also examined the utility of compound $\mathbf{2 a}$ to label human primary cells, such as healthy immune cells derived from peripheral blood. We examined the labeling capabilities of compound 2a in human neutrophils (both unstimulated and stimulated with phorbol myristate) and in monocyte-derived macrophages (both unstimulated and stimulated with liposaccharide). We acquired Z-stack fluorescence microscopy to analyze the cell labelling as well as the intracellular localization. As shown in Figure 3, we observed bright intracellular punctate structures in neutrophils, whereas the labeling in macrophages was distributed across the whole cytoplasm. 

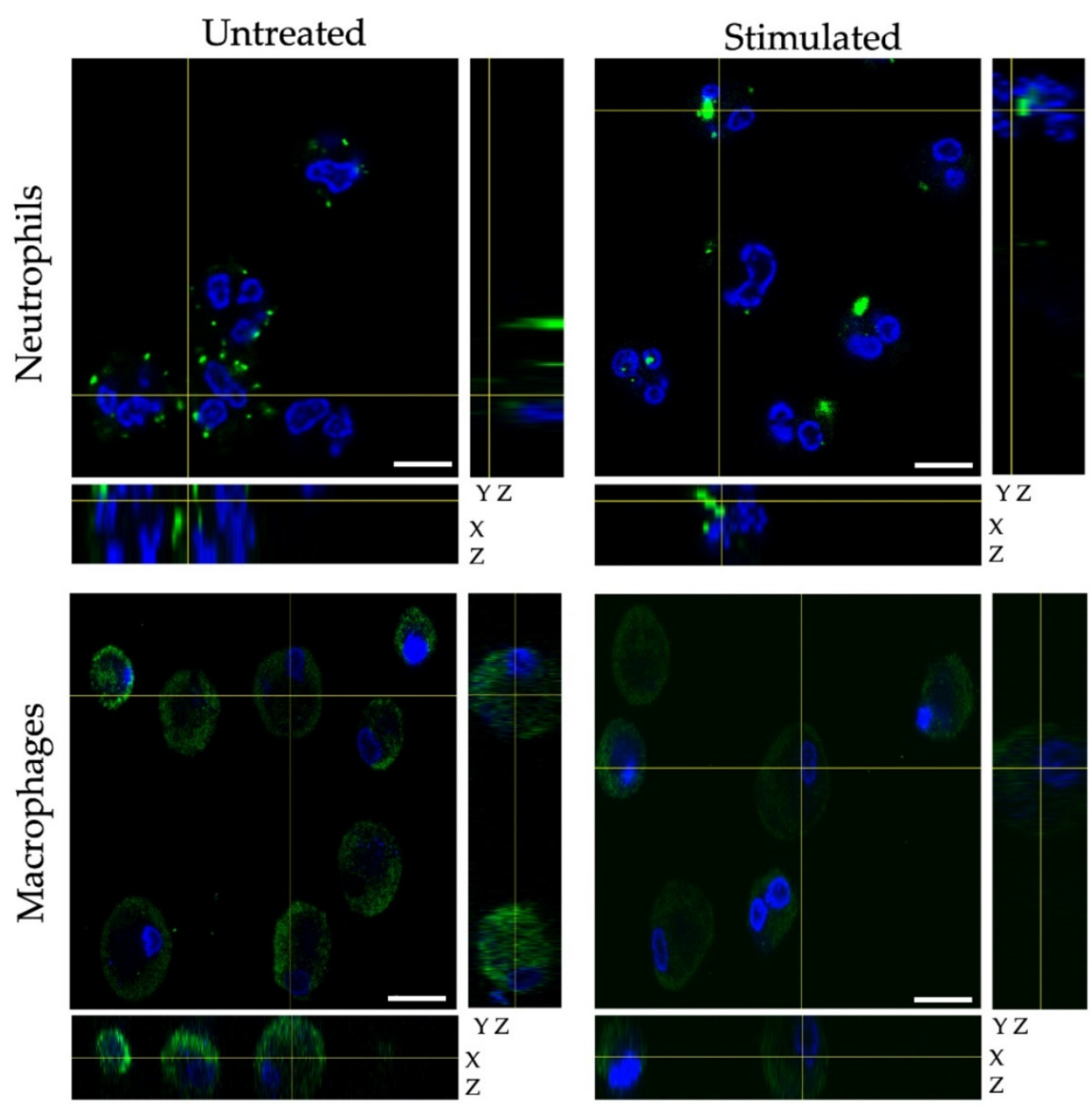

Figure 3. Z-stack confocal fluorescence microscopy images of neutrophils (untreated and PMAstimulated), and macrophages (untreated and LPS-stimulated). Cells were incubated with compound 2a $\left(10 \mu \mathrm{M}, \lambda_{\text {exc }}=488 \mathrm{~nm}, \lambda_{\mathrm{em}}=550-680 \mathrm{~nm}\right)$ and counterstained with Hoechst 33342 for nuclear labelling. Scale bar: $15 \mu \mathrm{m}$.

\section{Conclusions}

In conclusion, we reported a new synthetic approach to generate BODIPY derivatives under neat conditions and the preparation of novel 2,6-thioaryl-derivatized BODIPY compounds. The straightforward and selective functionalization of the BODIPY core by thiophenol chloride prepared in situ allows for easy modification and addition of targeting moieties. Analysis of the photophysical properties shows that thioaryl-BODIPY derivatives display large Stokes shifts, which can be advantageous for optical imaging. Finally, we have confirmed that thioaryl-BODIPYs are not toxic in mammalian cells at their working concentrations and can be used for fluorescence confocal microscopy in human cells of multiple origin.

Supplementary Materials: The following supporting information can be downloaded at: https: / / www.mdpi.com/article/10.3390/chemosensors10010019/s1, Figure S1: ORTEP-3 projection of compound 2d, Figure S2: absorption and emission spectra of compound $\mathbf{2 a}$ in different organic solvents, Figure S3: cell viability data, Figure S4: additional confocal microscopy images. Table S1: ORTEP-3 projection of compound $2 \mathrm{~d}$, showing the atom numbering and displacement ellipsoids at the $50 \%$ probability level.

Author Contributions: Conceptualization, E.N.d.S.J. and M.V.; investigation, A.E.R., C.L., A.G., L.A.M., M.C.d.S., F.F.C.M., C.A.d.S., M.M.G. and L.F.P.; resources, E.N.d.S.J. and M.V.; writing- 
original draft preparation, A.E.R., C.L., E.N.d.S.J. and M.V.; writing-review and editing, E.N.d.S.J. and M.V.; supervision, E.N.d.S.J. and M.V.; funding acquisition, E.N.d.S.J. and M.V. All authors have read and agreed to the published version of the manuscript.

Funding: This research was funded by CNPq (PQ 309774/2020-9), FAPEMIG (PPM-00635-18 and Rede de Pesquisa e Inovação para Bioengenharia de Nanossistemas (RED-00282-16), the Royal Society of Chemistry (RG160289), and an ERC Consolidator Grant (DYNAFLUORS, 771443).

Institutional Review Board Statement: The study protocol to work with human peripheral blood leukocytes was approved by the Accredited Medical Regional Ethics Committee (AMREC, 20-HV-069, University of Edinburgh).

Informed Consent Statement: Informed consent was obtained from all subjects involved in the study.

Data Availability Statement: Data available from the corresponding authors upon reasonable request.

Acknowledgments: M. C. de Souza, F. F. C. Marques, and L. F. Pedrosa acknowledge funding from the FAPERJ, CAPES, and CNPq. E. N. da Silva Júnior acknowledges funding from CNPq (PQ 309774/2020-9), CAPES, INCT-Catálise, FAPEMIG (PPM-00635-18 and Rede de Pesquisa e Inovação para Bioengenharia de Nanossistemas-RED-00282-16), Return Fellowship of the Alexander von Humboldt Foundation $(\mathrm{AvH})$, and the Royal Society of Chemistry for the research fund grant (RG160289). M.V. acknowledges funding from an ERC Consolidator Grant (DYNAFLUORS, 771443).

Conflicts of Interest: The authors declare no conflict of interest.

\section{References}

1. Lu, X.; Mestres, G.; Singh, V.P.; Effati, P.; Poon, J.F.; Engman, L.; Ott, M.K. Selenium- and Tellurium-Based Antioxidants for Modulating Inflammation and Effects on Osteoblastic Activity. Antioxidants 2017, 6, 13. [CrossRef] [PubMed]

2. Borges, F.; Zugman, T.; Bandeira, P.; Dalmolin, M.; Scariot, D.; Garcia, F.; De Oliveira, A.; Nakamura, C.; Piovan, L. Complementary Performance of Organoselenides and Organotellurides as Antimicrobials Agents. J. Braz. Chem. Soc. 2021, 32, 642-675. [CrossRef]

3. Galant, L.S.; Rafique, J.; Braga, A.L.; Braga, F.C.; Saba, S.; Radi, R.; da Rocha, J.B.T.; Santi, C.; Monsalve, M.; Farina, M.; et al. The Thiol-Modifier Effects of Organoselenium Compounds and Their Cytoprotective Actions in Neuronal Cells. Neurochem. Res. 2021, 46, 120-130. [CrossRef]

4. Jardim, G.A.M.; Lima, D.J.B.; Valença, W.O.; Cavalcanti, B.C.; Pessoa, C.; Rafique, J.; Braga, A.L.; Jacob, C.; da Silva Junior, E.N.; Da Cruz, E.H.G. Synthesis of Selenium-Quinone Hybrid Compounds with Potential Antitumor Activity via Rh-Catalyzed C-H Bond Activation and Click Reactions. Molecules 2017, 23, 83. [CrossRef] [PubMed]

5. Kharma, A.; Jacob, C.; Bozzi, Í.A.O.; Jardim, G.A.M.; Braga, A.L.; Salomão, K.; Gatto, C.C.; Silva, M.F.S.; Pessoa, C.; Stangier, M.; et al. Electrochemical Selenation/Cyclization of Quinones: A Rapid, Green and Efficient Access to Functionalized Trypanocidal and Antitumor Compounds. Eur. J. Org. Chem. 2020, 2020, 4474-4486. [CrossRef]

6. Vieira, A.A.; Brandão, I.R.; Valença, W.O.; de Simone, C.A.; Cavalcanti, B.C.; Pessoa, C.; Carneiro, T.R.; Braga, A.L.; da Silva, E.N. Hybrid compounds with two redox centres: Modular synthesis of chalcogen-containing lapachones and studies on their antitumor activity. Eur. J. Med. Chem. 2015, 101, 254-265. [CrossRef] [PubMed]

7. Benson, S.; de Moliner, F.; Fernandez, A.; Kuru, E.; Asiimwe, N.L.; Lee, J.-S.; Hamilton, L.; Sieger, D.; Bravo, I.R.; Elliot, A.M.; et al. Photoactivatable metabolic warheads enable precise and safe ablation of target cells in vivo. Nat. Commun. 2021, 12, 2369. [CrossRef] [PubMed]

8. Benson, S.; Fernandez, A.; Barth, N.D.; De Moliner, F.; Horrocks, M.H.; Herrington, C.S.; Abad, J.L.; Delgado, A.; Kelly, L.; Chang, Z.; et al. SCOTfluors: Small, Conjugatable, Orthogonal, and Tunable Fluorophores for In Vivo Imaging of Cell Metabolism. Angew. Chem. Int. Ed. 2019, 58, 6911-6915. [CrossRef]

9. Fernandez, A.; Thompson, E.J.; Pollard, J.W.; Kitamura, T.; Vendrell, M. A Fluorescent Activatable AND-Gate Chemokine CCL2 Enables In Vivo Detection of Metastasis-Associated Macrophages. Angew. Chem. Int. Ed. 2019, 58, 16894-16898. [CrossRef]

10. Mellanby, R.J.; Scott, J.I.; Mair, I.; Fernandez, A.; Saul, L.; Arlt, J.; Moral, M.; Vendrell, M. Tricarbocyanine N-triazoles: The scaffold-of-choice for long-term near-infrared imaging of immune cells in vivo. Chem. Sci. 2018, 9, 7261-7270. [CrossRef]

11. Zhao, C.; Fernandez, A.; Avlonitis, N.; Velde, G.V.; Bradley, M.; Read, N.D.; Vendrell, M. Searching for the Optimal Fluorophore to Label Antimicrobial Peptides. ACS Comb. Sci. 2016, 18, 689-696. [CrossRef]

12. Mendive-Tapia, L.; Subiros-Funosas, R.; Zhao, C.; Albericio, F.; Read, N.D.; Lavilla, R.; Vendrell, M. Preparation of a Trp-BODIPY fluorogenic amino acid to label peptides for enhanced live-cell fluorescence imaging. Nat. Protoc. 2017, 12, 1588-1619. [CrossRef] [PubMed] 
13. Park, S.-J.; Yeo, H.C.; Kang, N.-Y.; Kim, H.; Lin, J.; Ha, H.-H.; Vendrell, M.; Lee, J.-S.; Chandran, Y.; Lee, D.-Y.; et al. Mechanistic elements and critical factors of cellular reprogramming revealed by stepwise global gene expression analyses. Stem Cell Res. 2014, 12, 730-741. [CrossRef] [PubMed]

14. Zhang, X.; Chen, Y.; He, H.; Wang, S.; Lei, Z.; Zhang, F. ROS/RNS and Base Dual Activatable Merocyanine-Based NIR-II Fluorescent Molecular Probe for in vivo Biosensing. Angew. Chem. Int. Ed. Engl. 2021, 60, 26337-26341. [CrossRef]

15. Gao, M.; Lee, S.H.; Park, S.H.; Ciaramicoli, L.M.; Kwon, H.Y.; Cho, H.; Jeong, J.; Chang, Y.T. Neutro-phil-Selective Fluorescent Probe Development through Metabolism-Oriented Live-Cell Distinction. Angew. Chem. Int. Ed. Engl. 2021, 60, 23743-23749. [CrossRef] [PubMed]

16. Zhang, J.; Wang, L.; Jaschke, A.; Sunbul, M. A Color-Shifting Near-Infrared Fluorescent Aptamer-Fluorophore Module for Live-Cell RNA Imaging. Angew. Chem. Int. Ed. Engl. 2021, 60, 21441-21448. [CrossRef]

17. Scott, J.I.; Deng, Q.; Vendrell, M. Near-Infrared Fluorescent Probes for the Detection of Cancer-Associated Proteases. ACS Chem. Biol. 2021, 16, 1304-1317. [CrossRef] [PubMed]

18. Oe, M.; Miki, K.; Ohe, K. An enzyme-triggered turn-on fluorescent probe based on carboxylate-induced detachment of a fluorescence quencher. Org. Biomol. Chem. 2020, 18, 8620-8624. [CrossRef]

19. Nobori, T.; Kawamura, M.; Yoshida, R.; Joichi, T.; Kamino, K.; Kishimura, A.; Baba, E.; Mori, T.; Katayama, Y. Fluorescence Signal Amplification by Using beta-Galactosidase for Flow Cytometry; Advantages of an Endogenous Activity-Free Enzyme. Anal. Chem. 2020, 92, 3069-3076. [CrossRef]

20. Yao, C.; Li, Y.; Wang, Z.; Song, C.; Hu, X.; Liu, S. Cytosolic NQO1 Enzyme-Activated Near-Infrared Fluorescence Imaging and Photodynamic Therapy with Polymeric Vesicles. ACS Nano 2020, 14, 1919-1935. [CrossRef]

21. Wang, R.; Chen, J.; Gao, J.; Xu, G.; Zhu, T.; Gu, X.; Guo, Z.; Zhu, W.-H.; Zhao, C. A molecular design strategy toward enzymeactivated probes with near-infrared I and II fluorescence for targeted cancer imaging. Chem. Sci. 2019, 10, 7222-7227. [CrossRef]

22. Li, X.; Bottini, M.; Zhang, L.; Zhang, S.; Chen, J.; Zhang, T.; Liu, L.; Rosato, N.; Ma, X.; Shi, X.; et al. Core-Satellite Nanomedicines for in Vivo Real-Time Monitoring of Enzyme-Activatable Drug Release by Fluorescence and Photoacoustic Dual-Modal Imaging. ACS Nano 2018, 13, 176-186. [CrossRef] [PubMed]

23. Barth, N.D.; Subiros-Funosas, R.; Mendive-Tapia, L.; Duffin, R.; Shields, M.A.; Cartwright, J.A.; Henriques, S.T.; Sot, J.; Goñi, F.M.; Lavilla, R.; et al. A fluorogenic cyclic peptide for imaging and quantification of drug-induced apoptosis. Nat. Commun. 2020, 11, 1-14. [CrossRef]

24. Cheng, Z.; Kuru, E.; Sachdeva, A.; Vendrell, M. Fluorescent amino acids as versatile building blocks for chemical biology. Nat. Rev. Chem. 2020, 4, 275-290. [CrossRef]

25. Yraola, F.; Ventura, R.; Vendrell, M.; Colombo, A.; Fernàndez, J.-C.; De La Figuera, N.; Fernández-Forner, D.; Royo, M.; Forns, P.; Albericio, F. A Re-evaluation of the Use of Rink, BAL, and PAL Resins and Linkers. QSAR Comb. Sci. 2004, 23, 145-152. [CrossRef]

26. Zerfas, B.L.; Coleman, R.A.; Salazar-Chaparro, A.F.; Macatangay, N.J.; Trader, D.J. Fluorescent Probes with Un-natural Amino Acids to Monitor Proteasome Activity in Real-Time. ACS Chem. Biol. 2020, 15, 2588-2596. [CrossRef]

27. Kuru, E.; Lambert, C.; Rittichier, J.; Till, R.; Ducret, A.; Derouaux, A.; Gray, J.; Biboy, J.; Vollmer, W.; VanNieuwenhze, M.; et al. Fluorescent D-amino-acids reveal bi-cellular cell wall modifications important for Bdellovibrio bacteriovorus predation. Nat. Microbiol. 2017, 2, 1648-1657. [CrossRef] [PubMed]

28. Harkiss, A.H.; Sutherland, A. Recent advances in the synthesis and application of fluorescent $\alpha$-amino acids. Org. Biomol. Chem. 2016, 14, 8911-8921. [CrossRef]

29. Cheruku, P.; Huang, J.-H.; Yen, H.-J.; Iyer, R.S.; Rector, K.D.; Martinez, J.S.; Wang, H.-L. Tyrosine-derived stimuli responsive, fluorescent amino acids. Chem. Sci. 2015, 6, 1150-1158. [CrossRef]

30. Krueger, A.T.; Imperiali, B. Fluorescent Amino Acids: Modular Building Blocks for the Assembly of New Tools for Chemical Biology. ChemBioChem 2013, 14, 788-799. [CrossRef]

31. Subiros-Funosas, R.; Ho, V.C.L.; Barth, N.D.; Mendive-Tapia, L.; Pappalardo, M.; Barril, X.; Ma, R.; Zhang, C.B.; Qian, B.Z.; Sintes, M.; et al. Fluorogenic Trp(redBODIPY) cyclopeptide targeting keratin 1 for imaging of aggressive carcinomas. Chem. Sci. 2019, 11, 1368-1374. [CrossRef]

32. Fernandez, A.; Vermeren, M.; Humphries, D.; Subiros-Funosas, R.; Barth, N.; Campana, L.; MacKinnon, A.; Feng, Y.; Vendrell, M. Chemical Modulation of in Vivo Macrophage Function with Subpopulation-Specific Fluorescent Prodrug Conjugates. ACS Central Sci. 2017, 3, 995-1005. [CrossRef] [PubMed]

33. Subiros-Funosas, R.; Mendive-Tapia, L.; Sot, J.; Pound, J.D.; Barth, N.; Varela, Y.; Goni, F.M.; Paterson, M.; Gregory, C.D.; Albericio, F.; et al. A Trp-BODIPY cyclic peptide for fluorescence la-belling of apoptotic bodies. Chem. Commun. 2017, 53, 945-948. [CrossRef]

34. Li, W.; Gong, Q.; Guo, X.; Wu, Q.; Chang, F.; Wang, H.; Zhang, F.; Hao, E.; Jiao, L. Synthesis, Reactivity, and Properties of a Class of pi-Extended BODIPY Derivatives. J. Org. Chem. 2021, 86, 17110-17118. [CrossRef] [PubMed]

35. Maleckaitè, K.; Dodonova, J.; Toliautas, S.; Žilènaitė, R.; Jurgutis, D.; Karabanovas, V.; Tumkevičius, S.; Vyšniauskas, A. Designing a Red-Emitting Viscosity-Sensitive BODIPY Fluorophore for Intracellular Viscosity Imaging. Chem.—Eur. J. 2021, 27, 16768-16775. [CrossRef] [PubMed]

36. Nodeh-Farahani, D.; Bentley, J.N.; Crilley, L.R.; Caputo, C.B.; VandenBoer, T.C. A boron dipyrromethene (BODIPY) based probe for selective passive sampling of atmospheric nitrous acid (HONO) indoors. Analyst 2021, 146, 5756-5766. [CrossRef] 
37. Shi, W.-J.; Feng, L.-X.; Wang, X.; Huang, Y.; Wei, Y.-F.; Ma, H.-J.; Wang, W.; Xiang, M.; Gao, L. A near-infrared-emission azaBODIPY-based fluorescent probe for fast, selective, and "turn-on" detection of HClO/ClO- . Talanta 2021, 233, 122581. [CrossRef] [PubMed]

38. Schrage, B.R.; Nemykin, V.N.; Ziegler, C.J. BOSHPY Fluorophores: BODIPY Analogues with Single Atom Controlled Aggregation. Org. Lett. 2021, 23, 5246-5250. [CrossRef]

39. Deng, P.; Xiao, F.; Wang, Z.; Jin, G. A Novel BODIPY Quaternary Ammonium Salt-Based Fluorescent Probe: Synthesis, Physical Properties, and Live-Cell Imaging. Front. Chem. 2021, 9, 650006. [CrossRef]

40. Pandey, V.; Raza, K.; Sonowal, M.; Gupta, I. BODIPY based red emitters: Synthesis, computational and biological studies. Bioorg. Chem. 2020, 106, 104467. [CrossRef]

41. Bañuelos, J. BODIPY Dye, the Most Versatile Fluorophore Ever? Chem. Rec. 2016, 16, 335-348. [CrossRef] [PubMed]

42. Ulrich, G.; Ziessel, R.; Harriman, A. The Chemistry of Fluorescent Bodipy Dyes: Versatility Unsurpassed. Angew. Chem. Int. Ed. 2008, 47, 1184-1201. [CrossRef]

43. Loudet, A.; Burgess, K. BODIPY Dyes and Their Derivatives: Syntheses and Spectroscopic Properties. Chem. Rev. 2007, 107, 4891-4932. [CrossRef] [PubMed]

44. Zhang, J.; Wang, N.; Ji, X.; Tao, Y.; Wang, J.; Zhao, W. BODIPY-Based Fluorescent Probes for Biothiols. Chem.-Eur. J. 2020, 26, 4172-4192. [CrossRef]

45. Filatov, M.A. Heavy-atom-free BODIPY photosensitizers with intersystem crossing mediated by intramolecular photoinduced electron transfer. Org. Biomol. Chem. 2019, 18, 10-27. [CrossRef]

46. Wang, J.; Gong, Q.; Wang, L.; Hao, E.; Jiao, L. The main strategies for tuning BODIPY fluorophores into photosensi-tizers. J. Porphyr. Phthalocyanines 2020, 24, 603-635. [CrossRef]

47. Karges, J.; Kuang, S.; Maschietto, F.; Blacque, O.; Ciofini, I.; Chao, H.; Gasser, G. Rationally designed ruthenium complexes for 1and 2-photon photodynamic therapy. Nat. Commun. 2020, 11, 3262. [CrossRef]

48. Li, W.; Yang, J.; Luo, L.; Jiang, M.; Qin, B.; Yin, H.; Zhu, C.; Yuan, X.; Zhang, J.; Luo, Z.; et al. Targeting photodynamic and photothermal therapy to the endoplasmic reticulum enhances im-munogenic cancer cell death. Nat. Commun. 2019, 10, 3349. [CrossRef]

49. Ge, J.; Lan, M.; Zhou, B.; Liu, W.; Guo, L.; Wang, H.; Jia, Q.; Niu, G.; Huang, X.; Zhou, H.; et al. A graphene quantum dot photodynamic therapy agent with high singlet oxygen generation. Nat. Commun. 2014, 5, 4596. [CrossRef]

50. Squeo, B.M.; Pasini, M. BODIPY platform: A tunable tool for green to NIR OLEDs. Supramol. Chem. 2020, 32, 56-70. [CrossRef]

51. Kue, C.S.; Ng, S.Y.; Voon, S.H.; Kamkaew, A.; Chung, L.Y.; Kiew, L.V.; Lee, H.B. Recent strategies to improve boron dipyrromethene (BODIPY) for photodynamic cancer therapy: An updated review. Photochem. Photobiol. Sci. 2018, 17, 1691-1708. [CrossRef] [PubMed]

52. Boens, N.; Verbelen, B.; Ortiz, M.J.; Jiao, L.; Dehaen, W. Synthesis of BODIPY dyes through postfunctionalization of the boron dipyrromethene core. Coord. Chem. Rev. 2019, 399, 213024. [CrossRef]

53. Lv, F.; Tang, B.; Hao, E.; Liu, Q.; Wang, H.; Jiao, L. Transition-metal-free regioselective cross-coupling of BODIPYs with thiols. Chem. Commun. 2019, 55, 1639-1642. [CrossRef] [PubMed]

54. Goud, T.V.; Tutar, A.; Biellmann, J.-F. Synthesis of 8-heteroatom-substituted 4,4-difluoro-4-bora-3a,4a-diaza-s-indacene dyes (BODIPY). Tetrahedron 2006, 62, 5084-5091. [CrossRef]

55. Fron, E.; Coutiño-Gonzalez, E.; Pandey, L.; Sliwa, M.; Van der Auweraer, M.; De Schryver, F.C.; Thomas, J.; Dong, Z.; Leen, V.; Smet, M.; et al. Synthesis and photophysical characterization of chalcogen sub-stituted BODIPY dyes. New J. Chem. 2009, 33, 1490-1496. [CrossRef]

56. Palao, E.; Slanina, T.; Klán, P. Construction of the carbon-chalcogen (S, Se, Te) bond at the 2,6-positions of BODIPY via Stille cross-coupling reaction. Chem. Commun. 2016, 52, 11951-11954. [CrossRef]

57. Mulay, S.V.; Choi, M.; Jang, Y.J.; Kim, Y.; Jon, S.; Churchill, D.G. Enhanced Fluorescence Turn-on Imaging of Hy-pochlorous Acid in Living Immune and Cancer Cells. Chemistry 2016, 22, 9642-9648. [CrossRef]

58. Manjare, S.T.; Kim, J.; Lee, Y.; Churchill, D.G. Facile meso-BODIPY Annulation and Selective Sensing of Hypochlorite in Water. Org. Lett. 2013, 16, 520-523. [CrossRef]

59. Rezende, L.C.; Melo, S.M.; Boodts, S.; Verbelen, B.; Emery, F.S.; Dehaen, W. Thiocyanation of 3-substituted and 3,5-disubstituted BODIPYs and its application for the synthesis of new fluorescent sensors. Dye. Pigment. 2018, 154, 155-163. [CrossRef]

60. Kim, T.-I.; Park, S.; Choi, Y.; Kim, Y. A BODIPY-Based Probe for the Selective Detection of Hypochlorous Acid in Living Cells. Chem.-Asian J. 2011, 6, 1358-1361. [CrossRef]

61. Ahrens, J.; Böker, B.; Brandhorst, K.; Funk, M.; Bröring, M. Sulfur-Bridged BODIPY DYEmers. Chem.—Eur. J. 2013, 19, 11382-11395. [CrossRef] [PubMed]

62. Jameson, L.P.; Dzyuba, S.V.; Yoon, T.P. Expeditious, mechanochemical synthesis of BODIPY dyes. Beilstein J. Org. Chem. 2013, 9 , 786-790. [CrossRef] [PubMed]

63. Wurth, C.; Gonzalez, M.G.; Niessner, R.; Panne, U.; Haisch, C.; Genger, U.R. Determination of the absolute fluo-rescence quantum yield of rhodamine $6 \mathrm{G}$ with optical and photoacoustic methods-Providing the basis for fluorescence quantum yield standards. Talanta 2012, 90, 30-37. [CrossRef] [PubMed]

64. Brouwer, A. Standards for photoluminescence quantum yield measurements in solution (IUPAC Technical Report). Pure Appl. Chem. 2011, 83, 2213-2228. [CrossRef] 
65. Dransfield, I.; Buckle, A.M.; Savill, J.S.; McDowall, A.; Haslett, C.; Hogg, N. Neutrophil apoptosis is associated with a reduction in CD16 (Fc gamma RIII) expression. J. Immunol. 1994, 153, 1254-1263. [PubMed]

66. Sheldrick, G.M. SHELXT-Integrated space-group and crystal-structure determination. Acta Crystallogr. Sect. A 2015, 71, 3-8. [CrossRef] [PubMed]

67. Dolomanov, O.V.; Bourhis, L.J.; Gildea, R.J.; Howard, J.A.K.; Puschmann, H. OLEX2: A complete structure solution, refinement and analysis program. J. Appl. Crystallogr. 2009, 42, 339-341. [CrossRef]

68. Sheldrick, G.M. Crystal structure refinement with SHELXL. Acta Crystallogr. Sect. C 2015, C71, 3-8. [CrossRef]

69. Schlachter, A.; Fleury, A.; Tanner, K.; Soldera, A.; Habermeyer, B.; Guilard, R.; Harvey, P. The TDDFT Excitation Energies of the BODIPYs; The DFT and TDDFT Challenge Continues. Molecules 2021, 26, 1780. [CrossRef] [PubMed] 